\title{
"Foreign ownership and performance of listed firms: evidence from an emerging economy"
}

\author{
Phan Huu Viet
}

\begin{abstract}
Motivated by the relationship between foreign ownership and firm-level performances in emerging countries, we select Vietnam's listed market as the context for this empirical setting. We find that there is a significant inverted $U$ shaped relationship between foreign ownership and firm performances. The non-monotonic relationship is consistent with corporate governance theory on the gains from monitoring effects by shareholders or the losses from expropriations when their ownership exceeds a certain large level. Furthermore, we find that foreign investors disfavor firms with high concentration of ownership that relates to image of weak corporate governance. Lastly, there are also evidences that foreign investors are likely to invest in firms with good financial performances, large size, low level of debts, in pharmaceutical industry, and listed in higher liquid stock exchange.
\end{abstract}

Keywords: foreign ownership, ownership structure, corporate governance, performance, Vietnam.

JEL classification: G34, G39, L20.

\section{Introduction}

In the context of increased globalization of capital markets, many countries have gradually opened up their capital market to attract foreign investors (Bekaert and Harvey, 2000; Dahlquist et al., 2003). As a result, foreign ownership not only contributes to the development of capital market or the economic development of emerging countries, but has also become important actors in domestic ownership structure systems (Claessens, 1993; Errunza, 2001 and Ahmadjian et al., 2005). The question of whether foreign equity ownership relates with better firm-level performances is thus still a hotly debated subject in many countries. Corporate governance theory suggests incentive (monitoring) and entrenchment (pursuance of private benefits) effects of large shareholdings (Shleifer and Vishny, 1988; 
Claessens et al., 2002). There are also evidences indicating an inverted U shaped relationship between management or insider ownership and firm market valuation (Morck et al, 1988; McConnell and Servaes, 1990). Particularly, some studies suggest curvilinear association between ownership held by foreign investors and firm-level performances (Khanna and Palepu, 1999; Ferris and Park, 2005).

Aim at providing more evidences on the subject of foreign ownership, this study examines the relationship between ownership by foreign investors and firm-level performances. We use data of listed nonfinancial firms in Vietnam market ${ }^{(1)}$ from 2006-2010 for the study. According to existing regulations of the market, foreign investors can own up to $30 \%$ or $49 \%$ total shares of financial or nonfinancial firms, respectively.

We find that there is an inverted $U$ shaped relationship between foreign ownership and firm performances measured by Tobin's $\mathrm{Q}$ and ROA. The non-monotonic relationship is consistent with corporate governance theory on benefits from monitoring by shareholders and damages from expropriation when ownership of the shareholders reaches a certain large level (Shleifer and Vishny, 1986, 1997). In addition, the results are also in line with those of Morck et al. (1988), McConnell and Servaes (1990), Ferris and Park (2005) that find inverted $\mathrm{U}$ shaped relationship between insider (manager or foreigner) ownership and market value performance. Especially, Khanna and Palepu (1999) additionally provide evidences that foreign investors play efficient monitoring roles in emerging market. Based on market's context of the study, the results can be interpreted that foreign investors with minority ownership may play effective monitoring roles to mitigate agency problems of existing controlling shareholders; in contrast, the foreign investors with majority shareholder powers may connect with expropriations which will harm firm performances. The relationship is likely to be more sensitive in emerging economies with poor shareholder protection mechanisms. Furthermore, we find that foreign investors disfavor firms with high concentration of ownership that relates to image of weak corporate governance. Importantly, we find that foreign investors prefer high-performing firms, which supports argument on the causality relationship between foreign ownership and firm performances. Lastly, we also find significant evidence on determinants of foreign ownership such as firm size, debt level, types of industry and listing location.

(1) We consider Vietnam an appropriate market for the study because the market has several special institutional aspects determining effects of foreign ownership on firm-level performance such as poor shareholder protection mechanisms, low transparency (The World Bank, 2006; McGee, 2008). In addition, Vietnam is seen as one of frontier emerging markets and its nascent capital market is attracting special attention from foreign investors (Thanh and Quang, 2008; VCS, 2012). 
The study emphasizes more on relevant subjects of corporate governance, ownership structure, roles and impacts of certain shareholders, herein foreign owners, on the firms rather than aims at areas of investment valuation or investment strategy. The study contributes to current body of literature on the subject of foreign ownership in following aspects. First, to the best of our knowledge, this study may be one of the very first indications examining effects of foreign ownership on firm-level performances in Vietnam, an emerging country with nascent capital market and a least reached country for empirical studies in business-management disciplines. Second, we provide evidences that large foreign ownership in listed firms do not always associate with higher or more added benefits. The effects of foreign investors as firm shareholders should be thus evaluated with caution especially in environments with weak corporate governance and poor institutional aspects.

The study is organized as follows. Next section reviews the literature. Section 3 provides several features about Vietnam's equity market and foreign investor. Section 4 describes data and basic statistics. Section 5 presents empirical results and additional tests. Finally, Section 6 concludes the study.

\section{Literature review}

\subsection{Foreign ownership and firm performances}

Relationship of ownership structure and corporate value is widely discussed subjects in previous corporate governance literature. Classical studies of Jensen and Meckling (1976), Shleifer and Vishny (1997) suggest benefits of shareholders with large ownership by providing arguments that large shareholders have strong incentives to monitor managers, thus mitigate agency problems, which helps to maximize their firm's value. On the other hand, large shareholders can also relate to negative impacts on firm value. For example, large shareholders can pursue their own private interests that contradict those of other minority shareholders or those of employees and managers (Shleifer and Vishny, 1988). Therefore, it can be said that the relationship between ownership structure and corporate value is an empirical issue (McConnell and Servaes, 1990).

In addition, previous studies also examine the effects of management ownership and firm value. Berle and Means (1932) indicate that managers with little ownership can deploy managerial control for their private benefits rather than those of shareholders. For example, the managers can pursue non-value-maximizing objectives such as empire building and sales growth at the expense of other shareholders. Empirically, Morck et al. (1988) find a non- 
monotonic relationship between management ownership and firm market valuation. The authors argue that managerial ownership relates to higher firm market performance, but after a certain point of ownership, the managers become entrenched and execute decisions that are not for the benefit of other shareholders. Furthermore, McConnell and Servaes (1990) provide supporting evidences for the non-monotonic relationship by suggesting that there is a curvilinear relationship between ownership by corporate insiders and firm value. Firm value increases until the insider ownership reaches $40 \%-50 \%$, then after the levels, firm value decreases. Alltogether, Shleifer and Vishny $(1986,1997)$ suggest that there are gains from monitoring roles or losses from expropriation exercised by different types of shareholders depending on level of ownership they hold.

In the context of deeper integration of capital markets, many countries have gradually opened the door of their market to attract foreign investment, and foreign ownership varies across countries with different corporate governance mechanism and legal system (Bekaert and Harvey, 2000; Dahlquist et al., 2003). Although several obstacles preventing cross border investment still exist, foreign investors can now invest in most of the host countries directly or through mutual funds (Kang and Stulz, 1997). Foreign investors have gradually become important actors in domestic ownership structure systems (Ahmadjian et al., 2005). There are recent studies that emphasize on the relationship between ownership by foreign investor and firm market performance (Khanna and Palepu, 1999; Ferris and Park, 2005; Nakano and Nguyen, 2012).

Going into detail, Khanna and Palepu (1999) examine roles of foreign investors in India, an emerging economy. The authors discuss several aspects of India, particularly focusing on the lack of monitoring mechanism in the country's market. They find that foreign investors play valuable monitoring roles in their research context. In addition, Ferris and Park (2005) find that there is a curvilinear relation between firm value and the percentage of equity owned by foreign investors in Japan. Firm value raises and then declines after foreign ownership reaches approximately $40 \%$. Relying on previous corporate governance theory, Ferris and Park (2005) argue that manager-owner foreigners with their increased ownership may relate to entrenchment effects and act toward their managerial benefits against those of other shareholders. Also using data from Japan, Nakano and Nguyen $(2012)^{(2)}$ find positive linear

(2) In their study, it is possible to observe that foreign investors are generally non-controlling shareholders in majority of Japanese firms. Therefore, results of their study that show positive relationship between foreign ownership and firm value are relatively similar to the results of Ferris and Park (2005) who also point out benefits of minority foreign shareholders. 
association between foreign ownership and firm value in electronic industry. The authors suggest that foreign investors can bring added values by stamping out (or constraining) suboptimal behaviors of Japanese firms, thus playing certain governance roles to benefit their invested - firms.

Consistent with monitoring effects of foreign investors found in Khanna and Palepu (1999), and with positive side of foreign ownership suggested by Ferris and Park (2005), there are other evidences on the roles of foreign ownership on improvement of corporate governance. Kim et al. (2010) suggest that foreign investors in Korea are important catalysts in improving corporate governance. Furthermore, Gul et al. (2010), Mishra and Ratti (2011) indicate that foreign ownership in China relates to implemented actions toward better corporate governance practices. Specifically, their studies argue that roles of foreign indirect investors in listed firms are smaller when the firms are still being controlled by the State. Lastly, Oxelheim and Randoy (2003) support positive roles of foreign board members. They argue that the appearance of foreign board members is a signal for stronger commitments toward transparency and more advanced corporate governance. However, Anachotikul (2006) argues that foreign investors may pursue their potential private benefits at the expenses of other shareholders in the firm if their ownership is large enough to do so. They may also retain weak corporate governance with insufficient monitoring to create conditions which allow them to expropriate benefits from the firm.

Overall, based on the above evidences from previous literatures, there can be a hypothesis on the relationship between ownership by foreign investors and firm performances as illustrated by the inverted $U$ shaped graph: firm performances increase until foreign ownership reaches a turning point, and after a certain level of ownership, firm performances declines. 


\section{Graph 1: Hypothetical relationship between foreign ownership and firm performances}

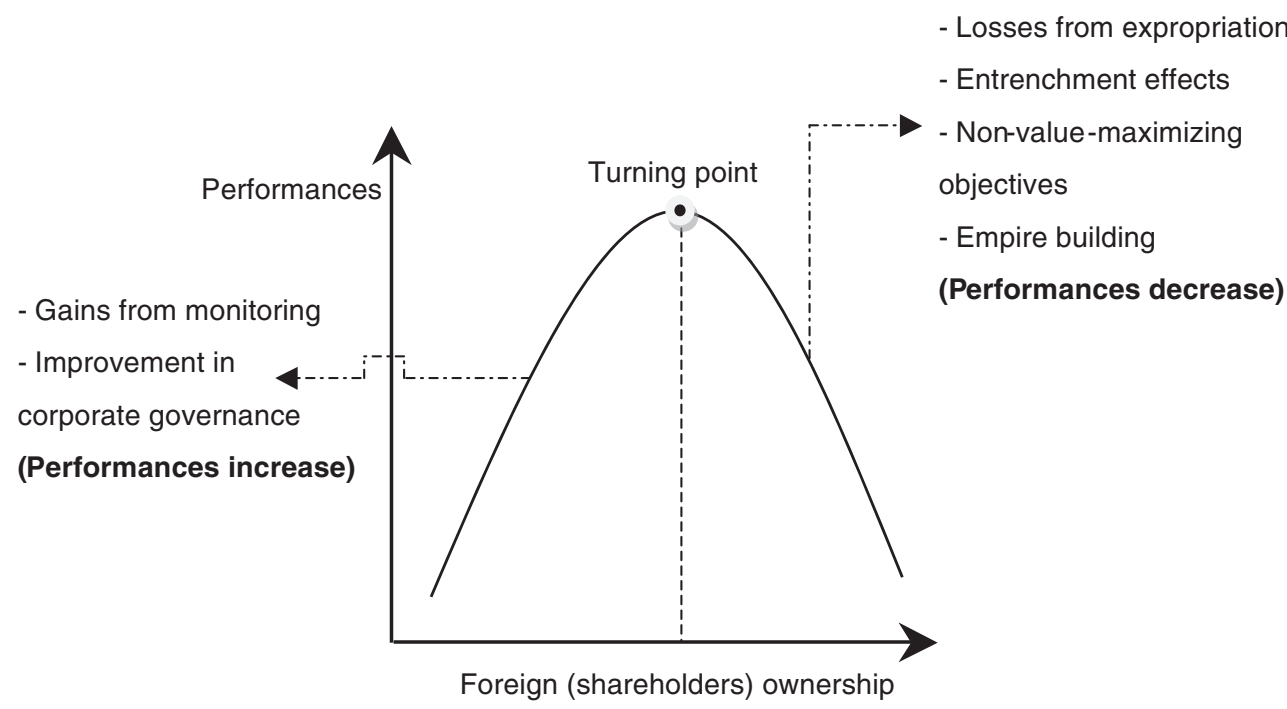

Last but not least, in their research, Ferris and Park (2005), Anachotikul (2006) and Nakano and Nguyen (2012) argue that there might be a causality relationship between foreign ownership and firm performances. In fact, foreign ownership may choose firm with good corporate governance to invest in (Kim et al., 2010). Therefore, issues of the causality relationship between foreign ownership and firm performances (and corporate governance) may overestimate the impacts of foreign ownership to the firm, which thus can be a serious matter when conducting research on the subject of foreign ownership.

\subsection{Determinants of foreign ownership}

Khanna and Palepu (1999) find that foreign investors are less likely to invest in firm groups that have weak corporate governance. Consistent to this argument, Giannetti and Simonov (2006) suggest that investors who enjoy only security benefits are reluctant to hold stocks in firms that show weak corporate governance and high probability of private benefit extraction. Indeed, questions of which firm characteristics determine level of foreign ownership are received attention from firm managers, market regulators and researchers, especially in emerging countries with newly-opened market. In their well-known study, Demsetz and Lehn (1985) examine determinants of ownership structure in firm. Their study suggests that size and value of the firm, shareholder's intention to control the firm, regulations (risks) and nature of industry are determinants affecting the ownership structure of the firm. Interestingly, their study does not reveal any relationship between foreign ownership and 
firm financial performance. This finding seems not to be consistent with common beliefs that foreign investors always pay attention to firm financial performance (profitability) before investing. In more detail, Kang and Stulz (1997), Lin and Shiu (2003) argue that foreign investors seem to favor firms which are in manufacturing industries, demonstrate less ownership concentration, show high accounting performance, have large size, bear low financial risk, and maintain high leverage. These findings also vary across countries with different economic and institutional conditions.

\section{Overview of Vietnam equity market and foreign investor}

Vietnamese securities market was officially inaugurated after the establishment of Ho Chi Minh Securities Trading Center (HOSE) on 20 July 2000. In 2005, Hanoi Securities Trading Center (HNX) was incorporated with only 9 firms listed. Meanwhile, there were only 32 firms listed in HOSE in 2005. During the last ten years, market capitalization to GDP is less than $20 \%{ }^{(3)}$, which was among the lowest in the Asia region. However, Vietnam equity market is seen as one of the fastest growing investment destinations, which is partly supported by privatization programs of the government ${ }^{(4)}$ (Merrill Lynch, 2006). As a result, at the end of 2011, there are nearly 800 companies listed in the two Stock Exchanges with approximately $40 \%$ of market cap to GDP. The significant increase in number of listed companies and market size derive from the fact that (i) privatization progress of state-owned enterprises is more aggressively implemented, (ii) private sector starts recognizing importance of stock market as a newly effective channel for mobilizing inside and outside capitals along with the traditional way of bank borrowings, (iii) especially, there is a large foreign indirect investment inflow to the nascent market, which is proved by increased existence of foreign investment funds and rapid growth in number of trading accounts of foreign individuals and institutions (HSBC, 2012). There are also evidences showing that Vietnam continues to be an attractive investment destination (HSBC, 2012) ${ }^{(5)}$. According to a new set of rankings published by Bloomberg (2012), Vietnam has been assessed as the top attractive "frontier" market. In addition, VCS (2012) shows that Vietnam is one of the few countries that demonstrates net foreign investment in-outflow and experiences less volatility in the amount of foreign investment.

\footnotetext{
(3) Market capitalization to GDP accelerated from $1.2 \%$ in 2005 to $37.6 \%$ in 2009 .

(4) See “Asian Insights - 2 Feb 2006” of Merrill Lynch (Merrill Lynch, 2006) for more details.

(5) HSBC (2012) shows that valuations of Vietnam's market seem reasonable: “...VN index's trailing PE is at 38\% discount to Asia ex Japan and a 27\% discount to MSCI Emerging Market...”
} 
This supports the expectation that foreign investors will keep eyeing Vietnam as a long-term investment destination with lots of opportunities and perspectives.

Along with the development of the equity market, Vietnam's State Securities Commission issued regulations to control and supervise the market operation and its players. Among the regulations, there are some that relate to foreign investors. According to Securities Law in Vietnam, foreign investors are generally allowed to own up to $49 \%$ and $30 \%$ in nonfinancial and financial-related firms, respectively. The restriction prevents further participation of foreign investors in firms and decrease liquidity of firm's shares. In addition, there are large numbers of listed firms which are used to be former wholly state-owned firms and the state ownership is still significantly largest ${ }^{(6)}$. For these firms, the proportions of shares that are freely available for trading are modest. It also prevents the expected ownership ratio of foreign investors. On average, foreign ownership in Vietnam listed firms is approximate 10\% to $13 \%$ (VCS, 2012). In spite of the continued efforts of the market regulators, legal framework, corporate governance such as monitoring and shareholder protection mechanism of the country's market, are weak and necessarily required for further improvement (IFC, 2010).

\section{Data}

\subsection{Data collection}

Our sample consists of 407 nonfinancial listed firms with a total of 1262 firm-year observations from 2006-2010. We collected financial performance ratios, foreign ownership, government ownership, and governance information of listed non-financial firms in two stock exchanges of Vietnam's market. In the study, foreign ownership is the main variable which is defined as the aggregate number of shares held by foreign investors in the listed firms.

We rely on OSIRIS, a professional data provider, to collect financial performance ratios of the listed firms. From the OSIRIS, important performance ratios such as Return on Assets and Return on Equities are automatically obtained. We also collect other year-end financial accounting indicators including Solvency, Sales, and Assets from the same source. To acquire foreign ownership and government ownership data, we use year-end versions (31/12) of Daily Securities Exchange Bulletins issued by Vietnamese two stock exchanges (HOSE and HNX) for the information. From the Bulletins, we can also have data on stock price and outstanding shares of the listed firms to calculate market capitalization. Lastly, governance information

(6) Around 74\% listed firms are former State-owned enterprises (SOEs) and are still under majority control of the State. 
of the listed firms such as years of listing, firm age, listing locations, Family firms, and State firms are derived from company profile in websites of GBIC Company, BIDV Securities Company (BSC) and VNEXPRESS (for identities of Family firms).

\subsection{Definition and use of firm performances}

We use Tobin's $\mathrm{Q}$ that reflects firm growth opportunities as a measurement of marketbased performance. The Tobin's $\mathrm{Q}^{(7)}$ is widely used in empirical studies of McConnell and Servaes (1990), Chung and Pruitt (1994), Khanna and Palepu (1999), Oxelheim and Randoy (2003), Ferris and Park (2005), Nakano and Nguyen (2012). As the calculation used in Oxelheim and Randoy (2003) and Villalonga and Amit (2006), Tobin's Q is calculated as the ratio of market capitalization to book value of total assets. We also use ROA measured by net income to total assets and ROE measured by net income to total equities as additional financial performance indicators.

\subsection{Calculation of weighted foreign ownership index}

We follow Dahlquist and Robertsson (2001), Chan et al. (2009) and Kim et al., (2010) to estimate the weighted foreign ownership index. Use of the weighted index is expected to take into account the differences in investment amounts by foreign investors in each firm relative to market portfolio. It is noted that the weighted index reflects percentage of foreign ownership in term of value and it is thus not as appropriate as normal foreign ownership to reflect level of control. The weighted index is calculated in a formula as follows:

$$
\text { Weighted index } x_{\mathrm{i}}=\frac{F_{i} / \sum_{i=1}^{n} F_{i}}{M_{i} / \sum_{i=1}^{n} M_{i}}-1
$$

where $F_{i}$ is market capitalization of foreign ownership of firm $i, \sum_{i=1}^{n} F_{i}$ is market capitalization of all foreign portfolio of all firms in the market. $M_{i}$ is market capitalization of firm $i, \sum_{i=1}^{n} M_{i}$ is the overall market capitalization of all firms. The weighted index reflects ratio of foreign ownership percentage of firm $i$ over value-weighted foreign ownership of the total market. Negative weighted index means that foreign investors invest more in firm $i$ comparing to market portfolio; inconstant, positive index implies that foreign investors invest less in firm $i$ relative to market portfolio. Alltogether, apart from normal foreign ownership

(7) See Chung and Pruitt (1994) for more details of Tobin's Q estimations. 
ratio, we use the weighted foreign ownership index as an additional ratio in robustness check as it can further examine the relationship between foreign ownership and firm performances.

\subsection{Summary Statistics}

Table 1 shows descriptive statistics of all variables in the sample. More detail of foreign ownership will be shown in Table 2. Important information of the Table 1 is the weighted foreign ownership index that has a minimum value of -1 and maximum value of 1.42 . Its average value of -0.50 means that on average, foreign investors invest less into their interested firms relative to the market portfolio. We also see that average value of Tobin's $Q$ is relatively small and close to 1 . Average ROA which reflects firm financial performance is $7.47 \%$. Average firm size measured by book value of assets is VND 946 billion ( US\$47.3 million). High standard deviation of firm value of assets reflects a high dispersion in firm scale. However, the size of Vietnam's listed firms is still relatively small versus international and regional standards. Average market capitalization of a Vietnam's listed firm was approximately US\$59.5 million at the end of 2010, which was much smaller than US\$432 million and US\$619 million of a Malaysia's and a Indonesia's listed firm, respectively (Nguyen et al., 2012).

Table 1: Descriptive statistics for all firm-year observations from 2006 to 2010

\begin{tabular}{|c|c|c|c|c|}
\hline Variables & Definition & Mean & Median & SD \\
\hline Fow & Percentage of foreign ownership (\%) & 10.00 & 4.00 & 13.00 \\
\hline Weighted Fow & Market-weighted average foreign ownership & -0.50 & -0.82 & 0.66 \\
\hline Tobin's Q & $\begin{array}{l}\text { Market-based performance (a proxy of firm value) measured } \\
\text { by market capitalization to book value of total assets }\end{array}$ & 0.86 & 0.54 & 0.98 \\
\hline ROA & Return on Assets measured by net incomes to assets (\%) & 7.47 & 6.28 & 8.47 \\
\hline Assets & Firm book value of assets (billion VND) & 946 & 349 & 1,940 \\
\hline Equity/Assets & Equity to Asset ratio & 49.24 & 47.08 & 22.32 \\
\hline Gow & Percentage of government ownership (\%) & 28.00 & 28.00 & 23.00 \\
\hline Firm_age & Firm age since firm incorporation (years) & 23.01 & 18.00 & 15.82 \\
\hline List_year & Year when firm lists & 2006.41 & 2006 & 1.96 \\
\hline List_place & $=1$ if firm lists in Ho Chi Minh, 0 in Hanoi stock exchange & 0.51 & 1.00 & 1.00 \\
\hline
\end{tabular}

Note: Firm_age, List_year and Assets will be in the form of logarithm when used as variables in later regressions.

Table 2 shows descriptive statistics for foreign ownership. Average foreign ownership is $10 \%$. Approximate $50 \%$ of listed firms in the sample have foreign ownership less than $3.5 \%$, which shows very low existence of foreign investors in many firms of the market. There are 
$25 \%$ and $5 \%$ number of listed firms having foreign ownership of larger than $13.9 \%$ and $43.2 \%$, respectively. In general, majority of firms (75\%) have small level of foreign ownership (less than 14\%). According to financial regulations in the country's market, there is a limitation on foreign ownership in listed firms. Maximum foreign ownership in non-financial and financial sectors is $49 \%$ and $30 \%$, respectively. In addition, shareholders with $10 \%$ ownership can have certain power to influence firm-related issues.

Table 2: Distribution of foreign ownership, Unit: \%

\begin{tabular}{cccccccccc}
\hline & $\mathrm{N}$ & Min & $\mathrm{p} 5$ & $\mathrm{p} 10$ & $\mathrm{p} 25$ & $\mathrm{p} 50$ & $\mathrm{p75}$ & $\mathrm{p} 95$ & Max \\
\hline Foreign ownership & 1259 & 0.0 & 0.0 & 0.1 & 0.7 & 3.5 & 13.9 & 43.2 & 49.0 \\
\hline
\end{tabular}

Note: p5...p95 representing 5\%...95\% percentile, respectively.

It is noticeable that average foreign ownership level is decreasing from $15.68 \%$ in 2006 to $10.15 \%$ in 2008 and to $7.60 \%$ in 2010 . However, with the rapid development of the country's stock market, there are large numbers of firms listed in recent years. (Thanh and Quang, 2008) Therefore, market capitalization of foreign ownership is indeed increasing regardless of the decreased ownership level. The industry classification is based on GICS (Global Industry Classification Standard). Regarding industry classification of listed firms in the sample, there are majority of listed firms from Capital goods (Electrical and machinery), Materials (Chemicals and construction), and Food, Beverage and Tobacco. From the sample, we also find larger percentage of foreign ownership in real estate, pharmaceutical and consumer service industries.

\section{Empirical results and additional tests}

\subsection{Relationship between foreign ownership and firm value}

\subsubsection{Empirical results}

In this section, we examine the relationships between foreign ownership of the listed firms and the firm performances. Following Petersen (2009), we employ robust OLS regressions clustered at firm level to control for heteroskedasticity within firms. To measure firm-level performances, we choose Tobin's Q (market-based performance) and ROA (financial accounting performance) as two performance indicators that are also used in previous studies (McConnell and Servaes, 1990; Chung and Pruitt, 1994, Khanna and Palepu, 1999; Ferris and Park 2005; Nakano and Nguyen, 2012). The two indicators are then used as dependent 
variables of the regressions.

The most important independent variable is foreign ownership. In the estimations, we use two indexes to represent ownership by foreign investors. The first index is normal foreign ownership that associates with percentage of total firm shares owned by foreign investors. The second index is weighted foreign ownership which is a ratio of firm's weight in foreign portfolio in comparison with the firm's weight in market portfolio. The weighted foreign ownership index is additionally used alongside with normal foreign ownership index because it controls for differences in the value of investment amounts made by foreign investors in different firms (Dahlquist and Robertsson, 2001; Chan et al., 2009). For instance, 50\% foreign ownership in a listed firm with market capitalization of US\$10 million is significantly different from $10 \%$ foreign ownership in other listed firm with market capitalization of US\$100 million.

The regression model is as follows.

$$
\begin{aligned}
& \text { Performances }_{j t}=\alpha+\beta_{1} \text { Fow }_{j t}+\beta_{2} \text { Squared fow }_{j t}+\beta_{3} \text { State }_{j t}+\beta_{4} \text { Family }_{j t}+\beta_{5} \text { Assets }_{j t}+ \\
& \beta_{6} \text { Firm_age }_{j t}+\beta_{7} \text { List_place }_{j t}+\beta_{8} \text { List_year }_{j t}+\beta_{9} \text { Equity } / \text { Asset }_{j t} \\
& +\beta_{10} \text { Year and industry dummies }{ }_{j t}+\varepsilon_{j t} \text {. }
\end{aligned}
$$

where dependent variables are Tobin's $\mathrm{Q}$ and ROA, $\varepsilon_{j t}$ is error term. Independent variables consist of Fow $_{j t}$ is percentage of foreign ownership of firm $j$ in year $t$; Squared_fow $w_{j t}$ is squared term of foreign ownership of firm $j$; State ${ }_{j t}$ is dummy variable that equals 1 if firm is controlled by the State (larger than 51\% ownership), 0 otherwise; Family ${ }_{j t}$ dummy variable that equals 1 if firm is controlled by founding family or individual founding member; Assets ${ }_{j t}$ is logarithm of total assets; Firm_age ${ }_{j t}$ is logarithm of firm age since incorporation; List_loca ${ }_{j t}$ is dummy variable that equals 1 if firm is listing in HOSE, 0 in HNX; List_year ${ }_{j t}$ is logarithm of year of listing; Equity/Asset ${ }_{j t}$ is measured by total equities to total assets. 
"Foreign ownership and performance of listed firms: evidence from an emerging economy"

Table 3: Relationship between foreign ownership and firm performances using normal foreign ownership

\begin{tabular}{|c|c|c|c|c|c|c|}
\hline & (1) & (2) & (3) & (4) & (5) & (6) \\
\hline & Tobin's Q & Tobin's Q & Tobin's Q & ROA & ROA & ROA \\
\hline \multirow[t]{2}{*}{ Fow } & $2.632^{\star * *}$ & $3.098^{\star \star *}$ & $2.443^{\star \star \star}$ & $18.43^{\star *}$ & $27.12^{\star \star \star}$ & $20.54^{\star *}$ \\
\hline & $(0.760)$ & $(0.870)$ & $(0.649)$ & (8.519) & $(9.064)$ & $(8.725)$ \\
\hline \multirow[t]{2}{*}{ Squared_fow } & $-4.132^{\star \star}$ & $-4.798^{\star \star}$ & $-4.361^{\star \star \star}$ & -30.440 & $-43.06^{\star}$ & $-33.10^{*}$ \\
\hline & $(1.787)$ & $(1.871)$ & (1.501) & $(20.880)$ & (21.930) & $(20.040)$ \\
\hline \multirow[t]{2}{*}{ State } & & 0.021 & 0.020 & & $1.793^{\star \star}$ & 1.305 \\
\hline & & $(0.091)$ & $(0.074)$ & & $(0.907)$ & $(0.859)$ \\
\hline \multirow[t]{2}{*}{ Family } & & -0.034 & -0.012 & & -0.235 & -0.483 \\
\hline & & $(0.096)$ & $(0.091)$ & & $(0.979)$ & $(0.981)$ \\
\hline \multirow[t]{2}{*}{ Assets } & & -0.057 & $0.0683^{\star \star}$ & & $-0.945^{\star \star \star}$ & 0.317 \\
\hline & & $(0.037)$ & $(0.031)$ & & $(0.325)$ & $(0.324)$ \\
\hline \multirow[t]{2}{*}{ Firm_age } & & -0.011 & 0.031 & & $1.088^{\star *}$ & $1.561^{\star \star \star}$ \\
\hline & & $(0.044)$ & $(0.035)$ & & $(0.505)$ & $(0.489)$ \\
\hline \multirow[t]{2}{*}{ List_place } & & & -0.135 & & & $-2.308^{\star * *}$ \\
\hline & & & $(0.082)$ & & & $(0.800)$ \\
\hline \multirow[t]{2}{*}{ List_year } & & & 0.139 & & & $2.791^{\star \star \star}$ \\
\hline & & & $(0.150)$ & & & $(0.800)$ \\
\hline \multirow[t]{2}{*}{ Equity/Asset } & & & $0.0154^{\star \star *}$ & & & $0.184^{\star \star \star}$ \\
\hline & & & $(0.002)$ & & & $(0.022)$ \\
\hline \multirow[t]{2}{*}{ Intercept } & $0.269^{*}$ & $1.415^{\star}$ & $-2.179^{\star \star \star}$ & $6.130^{\star \star *}$ & $19.95^{\star \star *}$ & $-18.79^{\star *}$ \\
\hline & $(0.142)$ & $(0.756)$ & $(0.749)$ & $(1.481)$ & $(6.896)$ & $(7.450)$ \\
\hline Year dummy & Yes & Yes & Yes & Yes & Yes & Yes \\
\hline Industry dummy & Yes & Yes & Yes & Yes & Yes & Yes \\
\hline Observations & 1241 & 1202 & 1129 & 1259 & 1220 & 1147 \\
\hline $\mathrm{R}^{\wedge} 2$ & 0.362 & 0.365 & 0.508 & 0.069 & 0.114 & 0.289 \\
\hline Adj. $R^{\wedge} 2$ & 0.355 & 0.356 & 0.5 & 0.059 & 0.102 & 0.277 \\
\hline
\end{tabular}

Standard errors are in parentheses. ${ }^{* * *},{ }^{* *},{ }^{*}$ denote the significance level at $1 \%, 5 \%$, and $10 \%$, respectively.

Results of Table 3 show that there is a significant relationship between foreign ownership and firm performances at 1\% level. Except for results of Model 4, other results are significant and similar for both normal and weighted foreign ownership. Particularly, the significant and positive (negative) signs of estimated coefficients of foreign ownership (its squared term) variables in all other five Models indicate that the foreign-ownership and performance relationship exists in an inverted $U$ shaped form. The results suggest that firm performances become better along side with the increase in level of foreign ownership, but when foreign ownership exceeds a turning point ${ }^{(8)}$, firm performances start decreasing.

(8) The turning points are considered optimal ownership level of foreign investors in the market context. 
Magnitudes of the coefficients show that turning points for the inverted U shaped relationship in case of Tobin's Q and ROA (Model 3 and Model 6) are 32\% and 31\%, respectively. Foreign ownership below the level (31\%-32\%) relates to higher performances, while foreign ownership above the level correlates to lower performances. In detail, if there is $1 \%$ change (100 basis points) in foreign ownership of lower or upper 31\%-32\% level, Tobin's Q increases by 0.024 or decrease by 0.024 , respectively. Similarly, $1 \%$ change (100 basis points) in foreign ownership of lower or upper $31 \%-32 \%$ level relates to $0.20 \%$ increase or decrease in ROA, respectively.

Table 4: Relationship between foreign ownership and firm performances using weighted foreign owneship ratio

\begin{tabular}{|c|c|c|c|c|c|c|}
\hline & $(1)$ & $(2)$ & (3) & (4) & (5) & (6) \\
\hline & Tobin's Q & Tobin's Q & Tobin's Q & $\mathrm{ROA}$ & $\mathrm{ROA}$ & $\mathrm{ROA}$ \\
\hline \multirow[t]{2}{*}{ Weighted Fow } & $0.531^{\star * *}$ & $0.625^{\star \star \star}$ & $0.493^{\star * *}$ & $3.656^{\star *}$ & $5.378^{\star \star \star}$ & $4.045^{\star \star}$ \\
\hline & $(0.153)$ & $(0.176)$ & $(0.131)$ & $(1.729)$ & $(1.836)$ & $(1.779)$ \\
\hline \multirow[t]{2}{*}{ Weighted Fow^2 } & $-0.168^{\star \star}$ & $-0.196^{\star \star}$ & $-0.178^{\star \star \star}$ & -1.204 & $-1.714^{*}$ & -1.304 \\
\hline & $(0.073)$ & $(0.076)$ & $(0.061)$ & $(0.860)$ & $(0.901)$ & $(0.826)$ \\
\hline \multirow[t]{2}{*}{ State } & & 0.021 & 0.020 & & $1.827^{\star \star}$ & 1.288 \\
\hline & & $(0.091)$ & $(0.074)$ & & $(0.909)$ & $(0.864)$ \\
\hline \multirow[t]{2}{*}{ Family } & & -0.034 & -0.012 & & -0.302 & -0.533 \\
\hline & & $(0.096)$ & $(0.091)$ & & $(0.977)$ & $(0.981)$ \\
\hline \multirow[t]{2}{*}{ Assets } & & -0.057 & $0.0683^{\star \star}$ & & $-0.916^{\star \star \star}$ & 0.339 \\
\hline & & $(0.037)$ & $(0.031)$ & & $(0.324)$ & $(0.324)$ \\
\hline \multirow[t]{2}{*}{ Firm_age } & & -0.011 & 0.031 & & $1.046^{\star \star}$ & $1.522^{\star \star \star}$ \\
\hline & & $(0.044)$ & $(0.035)$ & & $(0.502)$ & $(0.486)$ \\
\hline \multirow[t]{2}{*}{ List_place } & & & -0.135 & & & $-2.297^{\star * *}$ \\
\hline & & & $(0.082)$ & & & $(0.809)$ \\
\hline \multirow[t]{2}{*}{ List_year } & & & 0.139 & & & $2.764^{\star \star \star}$ \\
\hline & & & $(0.150)$ & & & $(0.818)$ \\
\hline \multirow[t]{2}{*}{ Equity/Asset } & & & $0.0154^{\star * *}$ & & & $0.184^{\star \star \star}$ \\
\hline & & & $(0.002)$ & & & $(0.023)$ \\
\hline \multirow[t]{2}{*}{ Intercept } & $0.269^{*}$ & $1.415^{\star}$ & $-2.179^{\star \star \star}$ & $6.178^{\star \star \star}$ & $19.50^{\star \star \star}$ & $-19.02^{\star \star}$ \\
\hline & $(0.142)$ & $(0.756)$ & $(0.749)$ & $(1.484)$ & $(6.896)$ & $(7.481)$ \\
\hline Year dummy & Yes & Yes & Yes & Yes & Yes & Yes \\
\hline Industry dummy & Yes & Yes & Yes & Yes & Yes & Yes \\
\hline Observations & 1241 & 1202 & 1129 & 1246 & 1207 & 1134 \\
\hline$R^{\wedge} 2$ & 0.362 & 0.365 & 0.508 & 0.071 & 0.115 & 0.288 \\
\hline Adj. $R^{\wedge} 2$ & 0.355 & 0.356 & 0.5 & 0.061 & 0.102 & 0.276 \\
\hline
\end{tabular}

Standard errors are in parentheses. ${ }^{* *},{ }^{* *},{ }^{*}$ denote the significance level at $1 \%, 5 \%$, and $10 \%$, respectively.

In addition to Table 3, we also use the weighted foreign ownership ratio as an alternative 
measurement of foreign shareholdings. Table 4 shows the relationship between valueweighted foreign ownership and firm performances. The results are less significant in the case of ROA, but remain strongly significant and similar to the results of Table 4 in the case of Tobin's Q. Generally, it can be said that the relationship between foreign ownership and firm performances exist in an inverted $\mathrm{U}$ shaped form.

The results are in line with studies of Morck et al. (1988) and McConnell and Servaes (1990) indicating significant non-monotonic relationship between Tobin's Q and management ownership. Especially, the results align with findings of Ferris and Park (2005) who reveal that there is also curvilinear relation between foreign ownership and firm value in Japan (but with a larger turning point of 40\%). Shleifer and Vishny $(1986,1997)$ suggest that ownership by shareholders correlates with gains from monitoring or with losses from expropriations when their ownership exceeds a certain large level. Supporting the view on expropriation by controlling shareholders, Claessens et al. (2002) find that there is a positive relationship between ownership concentration and the probability that minority shareholders can be expropriated. Anachotikul (2006) provides evidences that foreign investors with majority ownership may retain weak corporate governance to facilitate their potential expropriation in Thailand. In addition, strengthening the view on monitoring effects, Khanna and Palepu (1999) indicate that foreign investors serve as a good monitoring function in India.

From the country's market, it is possible to observe various positive monitoring cases in point by foreign shareholders such as raising voices in General Shareholder Meetings, monitoring performance and challenging responsibility of board of directors, nominating foreigner board members and requesting higher transparency in financial reporting and disclosure (The World Bank, 2006). Based on the findings of previous literature and the market current condition, we arrive at a potential interpretation that foreign investors with minority shareholder rights may play effective monitoring roles to reduce agency costs of existing controlling shareholders in the context of weak corporate governance practices. In contrast, the foreign investors with enough majority shareholder powers may connect with expropriations toward their private benefits, going against firm efficiency ${ }^{(9)}$. Particularly,

(9) There may be another interpretation that the negative relationship between firm performance and large foreign shareholdings resulted from a fact that foreign investors undertake investments into poorperforming firms through M\&A. Therefore, underperformance of the firm is not necessarily resulted from the impacts of foreign investors. Although, we checked announcements of publicly available M\&A deals in the market and found almost no evidences on the issue, we take the interpretation into special consideration for further study of the topic. 
the relationship will become more severe in environments with poor shareholder protection mechanisms. The results provide implications for market regulators and firm managers to take the best advantages of monitoring effects of foreign shareholdings ${ }^{(10)}$ as well as to improve the corporate governance practices at market - firm levels to mitigate the negative impacts of potential expropriation by controlling (foreign) shareholders.

\subsubsection{Further discussion of the results}

There is a concern that if ownership by foreigners is held by various minority foreign investors, it would be very difficult for some foreign shareholders with minority stake to have any influence on the behavior of invested firms. In fact, there is no evidence that foreign shareholders pursue collective actions or behave similarly in the real market context. Therefore, the interpretation of the empirical results will become weak if the concern cannot be probably justified. Taking the concern into careful consideration, we examine whether the ownership by foreigners are held by one large owner, or instead, by a collection of minority foreign investors. If the ownership is held by one large foreign investor, we may be able to presume they have the power for entrenchment. We select a list of listed firms in the sample that have larger than $30 \%$ of foreign ownership. The cut-off level of $30 \%$ is decided based on the turning point (31\%-32\%) of the inverted U shaped form found in the paper. And then, we check identities and ownership of major shareholders of listed firms in the list. We find that in nearly most of the cases, the largest (or second largest) shareholder of those firms is a foreign entity. Foreigner as the second largest shareholder is recorded in few firms which have very high level of government ownership. For instance: ABT (46.3\%, 10.8\%) - firms' name (ticker code) is $\mathrm{ABT}$, average foreign ownership is $46.3 \%$, and average ownership by the largest foreign shareholder is $10.8 \%$. Other firms include: BBC (48.2\%, 38.6\%), CII (40.8\%, 10.3\%), EVE (48.9\%, 16.8\%), HAP (30.5\%, 15.1\%), IFS (48.3\%, 29.6\%), KDC (32.6\%, 10.8\%), KMR (38.8\%, 21.5\%), MCV (37.4\%, 16.2), TCR (39.7\%, 29.2\%), TDH (36.5\%, 12.1\%), TKU (45.6\%, 15.0\%), TRI (10.1\%, 13.8\%), VFC (35.3\%, 25.4\%), and TYA (35.1\%, 20.1\%), respectively.

The ownership information indicates that ownership held by one foreign entity in the firms with larger than $30 \%$ of foreign ownership is relatively high. According to financial regulations in the market, shareholder with $10 \%$ ownership can exercise certain power to influence several important aspects of invested firms. Holding majority stake of at least

(10) As described in Table 2, 75\% of listed firms in our sample have less than $14 \%$ of foreign ownership, which suggests that foreign ownership generally relates to good impacts on performances of Vietnam's listed firms. 
$10 \%$ and being the largest (or second largest) shareholder may help the foreign investor facilitates conditions for entrenchment effects (expropriation) that weaken firm efficiencies. Therefore, for those firms, even though the behaviors of different foreign shareholders vary toward firm's value maximization purpose and their collective action may not exist, the largest foreign shareholder among foreign investor group may demonstrate overwhelming majority shareholder rights to influence behaviors of the invested firms at the expenses of other shareholders. The realistic and analytical information on identity and ownership of major shareholders of high-foreign-ownership-level firms, to some extent, ease the concern that foreign ownership may be dispersed to various minority foreign shareholders, making them difficult to influence firm-related issues. It thus supports the paper's interpretation and implication on the negative effects of foreign shareholders after their ownership reaches a certain high level.

\subsection{Determinants of foreign ownership}

There are evidences that issues of concentrated ownership may mitigate investment attention of foreign investors (Dahlquist et al., 2003). In addition, low transparency firm group reduces investment of foreign investors (Khanna and Palepu, 1999). It can be said that current conditions of corporate governance and ownership structure of the firm affect foreign investment decisions. To examine the above argument and other factors influencing level of foreign ownership of listed firms, we continue the study by examining determinants of foreign ownership.

From the sample, we can observe that the ownership structure of the Vietnam's listed firms is relatively concentrated. There is generally a biggest controlling shareholder who has significant voting power to influence all decisions of the firms. The first one is the State with majority of government ownership retained in the listed firms because those firms are former State-Owned Enterprises. The other one is the founding family who keeps holding significant owner rights in the listed firms. For these firms, corporate governance may be weak due to the lack of an effective monitoring mechanism exercised by the second largest (or minority) shareholders. Consequently, conflicts of interests between minority-majority shareholders, and between managers and owners of those firms become more severe (Claessens et al., 2002). 
Table 5: Determinants of foreign ownership

\begin{tabular}{|c|c|c|c|c|}
\hline & (1) & (2) & (3) & (4) \\
\hline & Fow & Weighted Fow & Fow & Weighted Fow \\
\hline \multirow[t]{2}{*}{ ROA } & $0.0009^{\star}$ & $0.0049^{*}$ & & \\
\hline & $(0.001)$ & $(0.003)$ & & \\
\hline \multirow[t]{2}{*}{$\mathrm{ROA}(\mathrm{t}-1)$} & $0.0010^{\star *}$ & $0.0052^{\star \star}$ & & \\
\hline & $(0.000)$ & $(0.002)$ & & \\
\hline \multirow[t]{2}{*}{ Tobin's Q } & & & 0.011 & 0.052 \\
\hline & & & $(0.007)$ & $(0.033)$ \\
\hline \multirow[t]{2}{*}{ Tobin's Q (t-1) } & & & $0.0136^{\star \star \star}$ & $0.0674^{\star * *}$ \\
\hline & & & $(0.005)$ & $(0.024)$ \\
\hline \multirow[t]{2}{*}{ Family } & $-0.0440^{\star \star}$ & $-0.218^{\star \star}$ & $-0.0403^{\star \star}$ & $-0.200^{\star *}$ \\
\hline & $(0.017)$ & $(0.085)$ & $(0.017)$ & $(0.083)$ \\
\hline \multirow[t]{2}{*}{ State } & $-0.0607^{\star \star *}$ & $-0.301^{* \star *}$ & $-0.0552^{\star * *}$ & $-0.273^{\star * \star}$ \\
\hline & $(0.012)$ & $(0.060)$ & $(0.012)$ & $(0.058)$ \\
\hline \multirow[t]{2}{*}{ Assets } & 0.017 & 0.083 & $0.0283^{\star \star \star}$ & $0.140^{\star \star *}$ \\
\hline & $(0.011)$ & $(0.056)$ & $(0.005)$ & $(0.024)$ \\
\hline \multirow[t]{2}{*}{ Firm_age } & 0.003 & 0.012 & 0.005 & 0.025 \\
\hline & $(0.006)$ & $(0.031)$ & $(0.006)$ & $(0.031)$ \\
\hline \multirow[t]{2}{*}{ List_year } & $-0.0959^{\star \star *}$ & $-0.470^{\star \star \star}$ & $-0.0951^{\star \star \star}$ & $-0.471^{\star * *}$ \\
\hline & $(0.017)$ & $(0.084)$ & $(0.015)$ & $(0.075)$ \\
\hline \multirow[t]{2}{*}{ List_place } & $0.0622^{\star \star \star}$ & $0.310^{\star \star \star}$ & $0.0354^{\star \star *}$ & $0.175^{\star \star \star}$ \\
\hline & $(0.023)$ & $(0.114)$ & $(0.013)$ & $(0.066)$ \\
\hline \multirow[t]{2}{*}{ Equity/Asset } & $0.0005^{\star}$ & 0.002 & $0.0006^{\star \star}$ & $0.0031^{\star \star}$ \\
\hline & $(0.000)$ & $(0.001)$ & $(0.000)$ & $(0.001)$ \\
\hline \multirow[t]{2}{*}{ Before 2008} & -0.001 & -0.002 & -0.003 & -0.016 \\
\hline & $(0.009)$ & $(0.042)$ & $(0.012)$ & $(0.060)$ \\
\hline \multirow[t]{2}{*}{ After 2008} & $-0.0104^{\star}$ & $-0.0529^{\star}$ & -0.006 & -0.028 \\
\hline & $(0.005)$ & $(0.027)$ & $(0.006)$ & $(0.028)$ \\
\hline \multirow[t]{2}{*}{ Industry 16} & $0.243^{\star \star \star}$ & $1.202^{\star \star \star}$ & $0.225^{\star \star \star}$ & $1.115^{\star \star \star}$ \\
\hline & $(0.028)$ & $(0.139)$ & $(0.031)$ & $(0.154)$ \\
\hline $\begin{array}{l}\text { Other industry } \\
\text { dummies }\end{array}$ & Yes & Yes & Yes & Yes \\
\hline \multirow[t]{2}{*}{ Intercept } & -0.104 & -0.517 & $-0.345^{\star \star \star}$ & $-1.710^{\star \star \star}$ \\
\hline & $(0.229)$ & $(1.141)$ & $(0.110)$ & $(0.544)$ \\
\hline Observations & 1146 & 1133 & 1116 & 1116 \\
\hline $\mathrm{R}^{\wedge} 2$ & 0.392 & 0.388 & 0.422 & 0.422 \\
\hline Adj. $R^{\wedge} 2$ & 0.382 & 0.377 & 0.412 & 0.412 \\
\hline
\end{tabular}

Standard errors are in parentheses. ${ }^{* *},{ }^{* *},{ }^{*}$ denote the significance level at $1 \%, 5 \%$, and $10 \%$, respectively.

In this section, we try to test determinants of foreign ownership in listed firms using robust OLS regressions clustered at firm level. Dependent variable of Model 1, 3 is normal foreign ownership. While, dependent variable of Model 2, 4 is the weighted foreign ownership 
ratio. We use either ROA or Tobin's Q and their one-year lag values to test whether foreign investors pay attention to high-performing firms. Other control variables such as family and state dummies (representing firm ownership structure), equity to asset ratio (representing level of debt), assets, firm age, listing location, years of listing, year and industry dummies (representing other important firm's characteristics) are included. Detail definition of the variables is mentioned in Specification (1) of section 5.1.

Results of Table 5 show that there are significant and positive relationships between foreign ownership and firm performances (and their lag values) in Model 1, 2 that use ROA as measurements of firm performances. Mode 3, 4 that use Tobin's Q only show positive and significant relationship in the lag values. The result supports the argument that foreign investors consider performance of the firm before investing. In other word, it reveals that high performing firms are likely to receive investments from foreign investors. The results enhance the argument of Ferris and Park (2005) and Nakano and Nguyen (2012) who suggest a causality relationship between foreign ownership and firm performance.

Furthermore, other important results of Table 5 are links between concentrated ownership structure and foreign involvement. Signs of coefficients of other control variables reveal that foreign investors disfavor firms that have high concentration of ownership which is presented by dominated shares owned by the state and the founding family. The result aligns with findings of Khanna and Palepu (1999) that reveal lower foreign investments in firm groups with limited transparency and poor corporate governance; and with those of Giannetti and Simonov (2006) who suggest that investors are reluctant to invest in firms with weak corporate governance. However, the results should be interpreted with care because it has been argued elsewhere that the state and the founding family are generally not willing or relatively conservative to reduce their ownership, which are main constraints preventing higher shareholdings of foreign investors.

Moreover, results of Table 5 also show that foreign investors seem to prefer large firms, which may be due to higher firm stock liquidity and higher market reputation. They are also likely to participate in firms with low debt, be listed in recent years, listed in more liquid stock exchange ${ }^{(11)}$, and in pharmaceutical industry. Overall, the findings are consistent with studies of Demsetz and Lehn (1985), Kang and Stulz (1997), Dahlquist and Robertsson (2001) about determinants of foreign ownership and controlling shareholders.

(11) Ho Chi Minh Stock Exchange demonstrates higher liquidation than Hanoi Stock Exchange (HSBC, 2010). 


\subsection{Additional tests}

There may be argument on endogeneity issue because foreign investors may choose firm with good corporate governance to invest, as suggested in the previous section (Kim et al., 2010). In their study, Ferris and Park (2005), Anachotikul (2006) and Nakano and Nguyen (2012) argue that there might be causality relationship between foreign ownership and firm performances. Therefore, issues of the causality relationship between foreign ownership and firm performances may distort the effects of foreign shareholders to invested firm. It is thus a serious matter which needs to be solved by appropriate research method. Ferris and Park (2005), Nakano and Nguyen (2012) have suggested some econometric methods to address the issue. In this section, we repeat some of their methods, as follows:

First, as the previous researchers, we employ 2-stage least squares (2SLS) method with an expectation to control for the causality issue. It is important to note that choosing appropriate instruments in 2SLS procedure is generally the most difficult or not always possible task because of limitation in numbers of exogenous variables in the sample or the lack of theoretical supporting evidences. Given these constraints, we consider to select oneyear lag value of performances which is already used in study of Nakano and Nguyen (2012) as the first instrument. In addition, we choose family firm dummy as the second instrument in our analysis. Panel 1 of Table 6 shows first stage regression that consists of (i) foreign ownership as endogenous variable and (ii) ROA (t-1) and family dummy as two instruments. Panel 2 of Table 6 contains similar variables as Panel 1 but ROA (t-1) replaced by Tobin's Q (t-1). Second stage regressions in Panel 3 of Table 6 show that there is significant inverted $U$ shaped relationship between foreign ownership and ROA (not for the case of Tobin's Q). In addition, significant results of Hausman tests lead to the conclusion that the foreign ownership variable is endogenous, suggesting the validity of the IVs. The results confirm our previous findings. In other words, firms with higher foreign ownership underperform those without. However, the magnitudes of coefficients of foreign ownership and its squared term climb to a relatively unreasonable level, which should be interpreted with caution ${ }^{(12)}$.

(12) As methods used in Ferris and Park (2005), Nakano and Nguyen (2012), we also employ 2-stage least squares (2SLS) with foreign ownership as endogenous variable and one-year lag values of performances as instrument. However, 2SLS regression results of the inverted U shaped relationship are not significant. 
Second, for other robustness check ${ }^{(13)(14)}$ of the empirical findings on the effect of the state or the family control, we use the ratio of shares held by these entities instead of their dummy variables. Since there are no sufficient data on ownership of founding family, we only use government ownership (and its squared term) as new independent variables. Table 7 displays the new empirical results. The results remain unchanged and significant at $5 \%$ and $1 \%$ level in term of Tobin's Q (consistent in signs of coefficients but not significant in case of ROA), supporting the inverted U shaped relationship between foreign ownership and firm performances. Lastly, we use Wald tests to check model specification. The significant results confirm suitability in the selection of the nonlinear regression models.

Table 6: 2SLS and validitty of the IVs

\begin{tabular}{|c|c|c|c|c|c|c|c|c|}
\hline \multirow{2}{*}{\multicolumn{3}{|c|}{$\begin{array}{l}\text { Panel 1: First stage } \\
\text { Endogenous and dependent } \\
\text { variable: Fow }\end{array}$}} & \multirow{2}{*}{\multicolumn{3}{|c|}{$\begin{array}{l}\text { Panel 2: First stage } \\
\text { Endogenous and dependent } \\
\text { variable: Fow }\end{array}$}} & \multicolumn{3}{|c|}{ Panel 3: Second stage } \\
\hline & & & & & & & \multirow[b]{2}{*}{$\mathrm{ROA}$} & (2) \\
\hline Fow & Coef. & Robust SD & Fow & Coef. & Robust SD & & & Tobin's Q \\
\hline $\mathrm{ROA}(\mathrm{t}-1)$ & $0.001^{\star *}$ & 0.000 & Tobin's Q (t-1) & $0.017^{\star \star \star}$ & 0.006 & Fow & $707.2^{\star * *}$ & 87.330 \\
\hline Family & $-0.058^{\star * *}$ & 0.011 & Family & $-0.054^{\star * *}$ & 0.011 & & $(238.600)$ & $(81.940)$ \\
\hline List_place & $0.064^{\star \star \star}$ & 0.012 & List_place & $0.039^{\star \star \star}$ & 0.009 & Squared_fow & $-1573.8^{\star \star *}$ & -198.600 \\
\hline State & $-0.062^{\star \star \star}$ & 0.008 & State & $-0.057^{* * *}$ & 0.008 & & (580.900) & $(196.100)$ \\
\hline Assets & $0.019^{\star \star \star}$ & 0.006 & Assets & $0.029^{\star \star \star}$ & 0.003 & List_place & $-9.785^{\star \star \star}$ & -1.193 \\
\hline List_year & $0.012^{\star * *}$ & 0.005 & List_year & $0.013^{\star \star \star}$ & 0.004 & & (3.567) & $(0.943)$ \\
\hline Equity/Asset & $0.001^{\star * *}$ & 0.000 & Equity/Asset & $0.001^{\star \star \star}$ & 0.000 & State & $5.002^{*}$ & 0.433 \\
\hline Intercept & $-0.384^{\star \star \star}$ & 0.118 & Intercept & $-0.598^{\star * *}$ & 0.074 & & $(2.573)$ & (0.398) \\
\hline Year dummy & Yes & & Year dummy & Yes & & Assets & $-4.479^{\star \star \star}$ & -0.382 \\
\hline Industry dummy & Yes & & Industry dummy & Yes & & & $(1.619)$ & $(0.371)$ \\
\hline Observations & 1,171 & & Observations & 1,141 & & List_year & -1.687 & -0.284 \\
\hline$F(17,1153)$ & $33.760^{\star * *}$ & & $F(17,1123)$ & $36.41^{\star * *}$ & & & $(1.487)$ & $(0.272)$ \\
\hline $\mathrm{R}^{\wedge} 2$ & 0.330 & & $\mathrm{R}^{\wedge} 2$ & 0.361 & & Equity/Asset & 0.020 & -0.001 \\
\hline Adj. $R^{\wedge} 2$ & 0.320 & & Adj. $R^{\wedge} 2$ & 0.351 & & & $(0.071)$ & $(0.012)$ \\
\hline \multirow[t]{9}{*}{ Root MSE } & 0.112 & & Root MSE & 0.108 & & Intercept & $70.12^{\star \star}$ & 5.245 \\
\hline & & & & & & & (29.190) & (5.734) \\
\hline & & & & & & Year dummy & Yes & Yes \\
\hline & & & & & & Industry dummy & Yes & Yes \\
\hline & & & & & & Observations & 1,171 & 1,141 \\
\hline & & & & & & Wald Chi2(17) & $36.460^{\star \star \star}$ & $34.880^{\star \star \star}$ \\
\hline & & & & & & Tests of endogeneity & & \\
\hline & & & & & & Robust score chi2(2) & $65.436^{\star \star \star}$ & $19.377^{\star \star \star}$ \\
\hline & & & & & & $\begin{array}{l}\text { Robust regression } \\
F(2,1151)\end{array}$ & $22.214^{\star \star \star}$ & $8.733^{\star \star \star}$ \\
\hline
\end{tabular}

Standard errors are in parentheses. ${ }^{* * *},{ }^{* *},{ }^{*}$ denote the significance level at $1 \%, 5 \%$, and $10 \%$, respectively.

(13) We thank the anonymous referee for suggesting this robustness check.

(14) Following Ferris and Park (2005), we use different cut-off levels of foreign ownership (5\%, 10\%, 25\%, 35\%, and $49 \%$ ) as independent dummy variables in the piecewise linear regressions to examine relationship between the foreign ownership and Tobin's Q. However, no significant results are found. 
Table 7: Relationship between foreign ownership and firm perforamnces using normal foreign ownership and new government ownership variable

\begin{tabular}{|c|c|c|c|c|}
\hline & (1) & (2) & (3) & (4) \\
\hline & Tobin's Q & Tobin's Q & $\mathrm{ROA}$ & ROA \\
\hline \multirow[t]{2}{*}{ Fow } & $2.044^{\star \star \star}$ & $2.117^{\star * *}$ & 16.270 & $19.16^{\star}$ \\
\hline & $(0.705)$ & $(0.694)$ & $(9.954)$ & $(9.861)$ \\
\hline \multirow[t]{2}{*}{ Squared_fow } & $-3.234^{\star \star}$ & $-3.393^{\star \star}$ & -20.010 & -27.210 \\
\hline & (1.589) & $(1.570)$ & $(22.360)$ & $(22.440)$ \\
\hline \multirow[t]{2}{*}{ Gow } & $0.870^{\star \star}$ & $0.462^{\star \star \star}$ & $22.89^{\star \star \star}$ & $6.717^{\star \star \star}$ \\
\hline & $(0.408)$ & $(0.138)$ & $(5.741)$ & (1.898) \\
\hline \multirow[t]{2}{*}{ Squared_gow } & -0.664 & & $-26.23^{\star \star *}$ & \\
\hline & $(0.571)$ & & (7.879) & \\
\hline \multirow[t]{2}{*}{ Family } & 0.127 & 0.103 & 1.861 & 0.896 \\
\hline & $(0.097)$ & $(0.095)$ & $(1.327)$ & $(1.243)$ \\
\hline \multirow[t]{2}{*}{ Assets } & 0.048 & 0.041 & 0.547 & 0.316 \\
\hline & $(0.031)$ & $(0.030)$ & $(0.354)$ & $(0.373)$ \\
\hline \multirow[t]{2}{*}{ Firm_age } & -0.011 & -0.008 & $1.473^{\star \star \star}$ & $1.609^{\star \star \star}$ \\
\hline & $(0.042)$ & $(0.042)$ & $(0.555)$ & $(0.559)$ \\
\hline \multirow[t]{2}{*}{ List_place } & -0.119 & -0.111 & $-2.614^{\star \star \star}$ & $-2.382^{\star \star \star}$ \\
\hline & $(0.083)$ & $(0.083)$ & $(0.839)$ & $(0.876)$ \\
\hline \multirow[t]{2}{*}{ List_year } & 0.104 & 0.098 & $3.230^{\star \star \star}$ & $2.939^{\star \star \star}$ \\
\hline & $(0.135)$ & $(0.133)$ & $(0.906)$ & $(0.965)$ \\
\hline \multirow[t]{2}{*}{ Equity/Asset } & $0.0145^{\star \star \star}$ & $0.0144^{\star \star *}$ & $0.196^{\star \star \star}$ & $0.193^{\star \star \star}$ \\
\hline & $(0.002)$ & $(0.002)$ & $(0.023)$ & $(0.023)$ \\
\hline \multirow[t]{2}{*}{ Intercept } & $-1.773^{\star *}$ & $-1.612^{\star \star}$ & $-27.35^{\star \star \star}$ & $-22.11^{\star \star}$ \\
\hline & $(0.703)$ & $(0.659)$ & $(8.418)$ & $(8.663)$ \\
\hline Year dummy & Yes & Yes & Yes & Yes \\
\hline Industry dummy & Yes & Yes & Yes & Yes \\
\hline Observations & 1129 & 1129 & 1147 & 1147 \\
\hline $\mathrm{R}^{\wedge} 2$ & 0.509 & 0.508 & 0.31 & 0.298 \\
\hline Adj. $R^{\wedge} 2$ & 0.497 & 0.497 & 0.294 & 0.283 \\
\hline
\end{tabular}

Standard errors are in parentheses. ${ }^{* *},{ }^{* *},{ }^{*}$ denote the significance level at $1 \%, 5 \%$, and $10 \%$, respectively.

\section{Conclusion}

Interested in the relationship between foreign ownership and firm-level performances in emerging countries, the study uses data of listed firms from 2006-2010 in Vietnam for the research target. Vietnam is an ideal context for the empirical setting because it is an emerging country with nascent and a recently-opened capital market that contains specific institutional characteristics. 
We find that there is an inverted $\mathrm{U}$ shaped relationship between foreign ownership and firm performances measured by Tobin's $Q$ and ROA. The non-monotonic relationship is consistent with corporate governance theory on the gains from monitoring effects and the losses from expropriations by shareholders when their ownership reaches a certain large level (Shleifer and Vishny, 1986, 1997). In addition, the results are also in line with those of Morck et al., (1988) and McConnell and Servaes (1990) that indicate a curvilinear relationship between management ownership and firm market valuation. The results also align with those of Ferris and Park (2005) that find similar foreign-value relationship in Japan, and with those of Khanna and Palepu (1999) that reveal monitoring effects of foreign investors in India. Even though, the study does not provide direct evidences explaining for the relationship, based on previous evidences on the same subject and the market's context, we interpret our results that foreign investors holding minority ownership may play effective monitoring roles to mitigate agency problems caused by existing controlling shareholders. On the other hand, foreign investors with enough majority ownership may use their powers for entrenchment. It also seems that the inverted $U$ shaped relationship is applied well in emerging countries with weak corporate governance and poor shareholder protection regime.

Furthermore, we also find that foreign investors disfavor firms with a high concentration of ownership that relates to an image of weak corporate governance. Importantly, we find that foreign investors prefer high-performing firms, which lead to a causality relationship between foreign ownership and firm performances. We use additional tests to address the issues but weakly significant results are found, especially in the case of firm performance measured by ROA. It may thus require further studies for the endogeneity issues. In addition, the identities of foreign owners may be needed for further investigation. Lastly, there are empirical evidences on determinants of foreign investment.

The study contributes on the current corporate governance literature by providing additional evidences on the inverted $U$ shaped relationship between foreign ownership and firm performances in an emerging country where there is rare empirical evidences on the theme. The results suggest that foreign ownership does not always relate with positive impacts and their effects thus should be evaluated under appropriate analyses. The study also provides implications for market regulators and firm managers to (i) improve corporate governance practices of listed firms for the potential reduction of expropriation risks caused by controlling shareholders, (ii) realize positive effects (monitoring) of foreign investors at either firm or country level, and (iii) further develop the country's nascent capital market by attracting more external funds. 


\section{*Acknowledgement:}

I would like to especially thank the anonymous referee for the very helpful comments.

I would also like to express my deepest gratitude to Professor Katsuyuki Kubo for his continued encouragement, most useful academic guidance and valuable comments during the research process. The paper benefited from useful discussions from participants at Waseda Student Research Seminar. I am also indebted to Mr. Chairman, Executive Managers of Saigon Securities Incorporation (SSI) and friends at Investment Banking Division, the SSI for providing an excellent working and research environment during my internship at the organization (March 2011), which helped me update conditions of Vietnam's financial market.

\section{References}

1. Ahmadijan C, Robbins G. A clash of capitalism: foreign shareholders and corporate restructuring in 1990s Japan. American Sociological Review 2005; 70; 451-471.

2. Ananchotikul S. Do foreign investment improve corporate governance? Evidence from Thailand. Department of Economics, University of California, Berkeley 2006.

3. Berle A and Means C. The modern corporation and private property. Macmillan, New York 1932.

4. Bekaert G, Harvey, C. Foreign speculator and emerging equity markets. The Journal of Finance 2000; 2; 565-613.

5. Benfratello L, Sembenelli A. Foreign ownership and productivity: Is the direction of causality is so obvious. International Journal of industrial Organization 2006; 24; 733-751.

6. Bloomberg. The 14 Most Exciting Frontier Markets in The World. Bloomberg Markets 2012.

7. Chan K, Covrig V, Ng L. Does home bias affect firm value? Evidence from holding of mutual funds worldwide. Journal of International Economics 2009; 78; 230-241.

8. Chen G, Firth M., Xu L. Does the type of ownership control matter? Evidence from China's listed companies. Journal of Banking and Finance 2009; 33; 171-181.

9. Chung K, Pruitt S. A simple approximation of Tobin's Q. Financial Management 1994; 23:3; 70-74.

10. Claessens S. Equity portfolio investment in developing countries: a literature survey. Working Paper Series, International Economics Department, The World Bank 1993.

11. Claessens S, Djankov S, Fan J, Lang L. Disentangling the incentive and entrenchment effects of large shareholdings Journal of Fiannce 2002, 57, 2741-2771.

12. Dahlquist M, Pinkowitz L, Stulz R, Williamson R. Corporate Governance and the home bias. Journal of Financial and Quantitative Analysis 2003; 38; 87-110.

13. Dahlquist M, Robertsson G. Direct foreign ownership, institutional investor and firm characteristics. Journal of Financial Economics 2001; 59; 413-440.

14. David G, Alessandra G, Zhihong Y. The more the better? Foreign ownership and corporate performance in China. University of Nottingham 2006.

15. Demsetz H, Lehn K. The structure of corporate ownership: causes and consequences. Journal of Political Economy 1985; 93; 6 . 
"Foreign ownership and performance of listed firms: evidence from an emerging economy"

16. Doms M, and Jensen J. Comparing wages, skills, and productivity between domestically and foreign-owned manufacturing establishment in the United State. Geography and Ownership as Bases for Economic Accounting; University of Chicago Press 1998.

17. Errunza V. Foreign portfolio equity investments, financial liberalization, and economic development. Review of International Economics 2001, 9:4, 703-726.

18. Ferris S, Park K. Foreign ownership and firm value: evidence from Japan. Advances in Financial economics 2005, 11, 1-29.

19. Giannetti M and Simonov A. Which investors fear expropriation? Evidence from investor's portfolio choices. The Journal of Finance 2006, 3, 1507-1547.

20. Gul F, Kim J, Qiu A. Ownership concentration, foreign shareholding, audit quality, and stock price synchronicity: evidence from China. Journal of Financial Economics 2010; 95; 425-442.

21. Guo S and Fraser M. Propensity score analysis: statistical methods and applications. Advanced Quantitative Techniques in the Social Science Series 2008.

22. HSBC. Vietnam insights: take a fresh look. Equity Strategy November 2010. HSBC Global Research 2010.

23. HSBC. Vietnam at a glance. Economics Vietnam Macro, HSBC Global Research 2012.

24. IFC. Corporate governance manual in Vietnam - second edition. Vietnam Corporate Governance Project, the World Bank 2010.

25. Jensen $\mathrm{M}$ and Meckling W. Theory of the firm: managerial behavior, agency costs, and ownership structure. Journal of Financial Economics 1976, 3, 305-360.

26. Kang J, Stulz M. Why is there home bias? An analysis of foreign portfolio equity ownership in Japan. Journal of Financial Economics 1997; 46; 3-28.

27. Khanna T and Palepu K. Emerging market business groups, foreign investors, and corporate governance. NBER Working Paper Series 1999, National Bureau of Economic Research.

28. Kim I, Kim J, Kim W, Byun S. Foreign investor and corporate governance in Korea. Pacific-Basin Finance Journal 2010; 18; 390-402.

29. Kolasa M, Rubaszek M, Taglioni D. Firms in the great global recession: the role of foreign ownership and financial independence. Emerging Markets Review 2010; 11; 341-357.

30. La Porta R, Lopez-De-Silanes F, Shleifer A. Corporate ownership around the world. Journal of Finance 1999; 2 ; 471-517.

31. Lin, Chihuang, Shiu C. Foreign ownership in Taiwan stock market - an empirical analysis. Journal of Multinational Financial Management 2003; 13; 19-41.

32. McConnell J, Servaes H. Additional evidence on equity ownership and corporate value. Journal of Financial Economics 1990; 27; 595-612.

33. McGee R. Corporate governance in Asia: a comparative study. Working Paper Series, College of Business Administration, Florida International University 2008.

34. Merrill Lynch. Asian Insights. Market report 2006.

35. Mishra A, Ratti R. Governance, monitoring and foreign investment in China companies. Emerging Market Review 2011; $12 ; 171-188$.

36. Morck R, Shleifer A and Vishny R. Management ownership and market valuation: an empirical analysis. Journal of Financial Economics 1988, 20, 293-315.

37. Nakano M, Nguyen P. Foreign ownership and firm performance: evidence from Japan's electronics industry. Applied Financial Economics 2012, 23:1, 41-50. 
"Foreign ownership and performance of listed firms: evidence from an emerging economy"

38. Nguyen DT, Nguyen TP, Nguyen J. Vietnam's SCIC: a gradualist approach to sovereign wealth funds. Journal of Asia Pacific Economy 2012, 17:2, 268-283.

39. Oxelheim L, Randoy T. The impact of foreign board membership on firm value. Journal of Banking and Finance 2003; 27; 2369-2392.

40. Petersen R. Estimating standard errors in finance panel data sets: comparing approaches. Review of Financial Studies 2009, 22, 435-480.

41. Shleifer A, Vishny R. Large shareholders and corporate control. Journal of Political Economy 1988; 94; 461488.

42. Shleifer A, Vishny R. A survey of corporate governance. Journal of Finance 1997; 42; 737-783.

43. Tesar L, Werner I. Home bias and high turnover. Journal of International Money and Finance 1995; 14; 467-492.

44. Thanh V and Quang P. Managing capital flows: the case of Vietnam. ADB Institute Discussion Paper No.105, ADB Institute, 2008.

45. The World Bank. Corporate governance, country assessment, Vietnam. Report on the Observance of Standards and Codes (ROSC) 2006.

46. VCS. Strategy report: Vietnam prospective in 2012. Viet Capital Securities 2012.

47. Villalonga B and Amit R. How do family ownership, control and management affect firm value? Journal of Economics 2006; 80; 385-417. 